\title{
ResearchOnline@JCU
}

This is the Accepted Version of a paper published in the journal Cultural Geographies:

Law, Lisa (2001) Home Cooking: Filipino Women and

Geographies of the Senses in Hong Kong. Cultural Geographies, 8 (3). pp. 264-283.

http://dx.doi.org/10.1177/096746080100800302 


\title{
HOME COOKING: FILIPINO WOMEN AND GEOGRAPHIES OF THE SENSES IN HONG KONG
}

\author{
Lisa Law
}

Originally published in Ecumene 8(3):264-283

This paper considers how migrant women become embodied subjects in foreign cities. It draws on the experiences of Filipino domestic workers in Hong Kong, and their active creation of places in the city that emulate a 'sense' of home (through sights, sounds, tastes, aromas and so on). Rather than explicate extreme forms of bodily experience some women mediate in their working lives - such as physical containment, hunger or violence - I interrogate unconventional forms of body politics that take place outside Hong Kong homes. In examining spaces of the city where Filipinas engage in mass leisure activities, I shed light on the relationship between space, bodies and sensory experience. The senses are not merely an intrinsic property of the body - they are a situated practice that connects the body to overlapping spaces of power in the cultural economy of labour migration. By linking sensory experience to urban culture and power relations in the city, I offer alternative maps of people and places that tell us something different about diasporic experience and the political importance of geographies of the senses.

Architecture, because it is always assumed to be somewhere, is the first visual evidence of a city's putative identity. In this regard, the symbolic landscape of Central exerts a particular fascination not only for filmmakers and photographers, but also for the domestic workers from the Philippines who take it over on Sundays when it is closed to traffic. ${ }^{1}$

My first visit to Hong Kong was in 1994. Like every dutiful tourist, topping my agenda was a Star Ferry ride from Kowloon to Hong Kong Island. The Star Ferry affords spectacular views of urban hyperdensity, and provides ample photo opportunities to capture the symbolic landscape that has come to represent the Hong Kong experience. One Sunday I boarded the ferry at Tsim Sha Tsui, took a few photographs as we crossed the channel, then disembarked at the Central terminal. As I wandered through the tunnels and streets leading up to the space-age architecture of the Hong Kong and Shanghai Bank, my focus shifted from monuments to people as it became evident I was among an exclusively Filipino community. While stories of the gathering at Central are common in the Philippines, I was not prepared for the intensity of the crowd.

My first and most profound memory of this experience was awakening to the phenomenon. In the distance a woman was bellowing 'peso, peso, pesooooo!' in the melodic tone used by street vendors to solicit business in the Philippines. The peso is the Philippine national currency, but this locution is difficult to express literally. In musical terms it is generally patterned in three measures of two beats, with the first beat of each measure somewhat staccatoed. The first five notes are the same, but are followed by a final prolonged note which ascends a full octave (this explanation, without doubt, will not do it justice). For me that voice, that particular rhythm and intonation, recalled the Philippines I had known from 1991 to 1993. My pace quickened as I was 
irresistibly lured towards it. A few moments later I found myself at one corner of Statue Square, where an entrepreneurial woman was trading Filipino pesos for Hong Kong dollars at rates slightly higher than local banks. It was the convenience of trading currency at this busy spot, she explained, and there were always domestic workers needing to buy pesos for travelling to the Philippines or to include a little cash for financially worse-off relatives in their regular letters home.

Ask any Filipino domestic worker what they do in Hong Kong on a Sunday, and you will be told about the spectacular gathering dubbed 'Little Manila'. In and around Central Hong Kong more than 100,000 Filipino women cast off the cultural conventions of their Chinese employers for one day a week, and eat Filipino food, read Filipino newspapers/magazines and consume products from an abundant number of Filipino specialty shops. It is not unusual to see women procuring manicures or haircuts on the pavement, or having group photographs taken in the street. The queues for the phone booths and at the post office are a sight in themselves, and when domestic workers are not posting letters or chatting long-distance they are writing and reading letters to and from distant loved ones. This ritual gathering has taken place since the early 1980s and is now a spectacle of modern life in Hong Kong.

My fleeting but intense encounter is relevant to geographical discussions about space, place and culture. Moving from the visual consumption of Central Hong Kong to the aural recognition of Little Manila, it signifies the everyday experience of cultural difference and suggests that the senses might play a vital role in mediating the spaces of multicultural cities. This vignette also imagines the possibility of appreciating cultural difference as an embodied encounter, and how space/place might help constitute embodied subjects. While this approach may not appear particularly novel, relatively little attention has been paid to processes of embodiment that consider the interrelationships between bodies and senses in the city. Despite feminist critiques of vision, or research into the politics of music and soundscapes, the senses are often assumed to be an intrinsic property of the body - a natural and unmediated aspect of human being. Here I argue that the senses are far from innocent; they are a situated practice that can shed light on the way bodies experience different spaces of culture.

To address these issues I introduce Little Manila, a place that could at once appear a cliché, an ethnic enclave, a site of resistance. Each week it disrupts the hegemonic space of Central Hong Kong, and local perceptions of this gathering as a disorderly crowd of unruly foreign women call attention to multicultural tensions in the city's urban fabric. When experienced from the inside, however, Statue Square and its environs become a home from away from home for migrant women, a place of remembering and forgetting, and a lively place full of laughter, songs and home cooking. Rather than reduce Little Manila to a site of resistance, where domestic workers merely repudiate their servant status in the metropolis, here I unravel some of the relationships between personal, urban and transnational space these women negotiate on a weekly basis.

Although the politics of more quotidian forms of sensory knowledge and feeling are not easily decipherable, Seremetakis has argued that 'a politics of sensory creation and reception [is] a politics of everyday life'. ${ }^{2}$ Taking this assertion seriously, I argue that the senses tell us something different about the politics of diasporic experience and suffuse diverse spaces in the city with new meaning. Little Manila is where domestic workers recover from more subtle forms 
of sensory reculturation that occur in Chinese homes, and in the process they create new ways of engaging with city life. It is also a place where Filipino women express a creative subjective capacity with the potential to displace the hegemonic images that describe their lives and work if only for one day a week.

One way to imagine how bodies and spaces are produced in Central is to consider different 'senses' of the city. Recasting the senses as a situated practice allows the gathering in Little Manila to be a form of embodied experience that both 'takes place' and is 'produced'. Mapping 'sensuous geographies' ${ }^{3}$ through an 'anthropology of the senses' ${ }^{4}$ provides new ways of connecting the cultural spaces of Hong Kong and the Philippines, revealing more subtle forms of power that are experienced across aesthetic practices. Eating Filipino food in Little Manila is a particularly good example. Food is significant for its ability to evoke a multifaceted experience of place, for by cooking and eating Filipino food on Sundays, domestic workers consume different experiences of Hong Kong, home and nation.

This paper moves through three parts. In the first part Little Manila is contrasted with women's experiences in the domestic sphere during the six-day working week. Although the stories told represent extreme forms of maltreatment reported to non-government organizations, they also suggest a cultural context that gives Little Manila its tactical meaning. I engage with Foucauldian perspectives of power which privilege the visual to theorize the relationship between these private/public spaces, but argue that accounts which stress discourse or vision tend to reduce Central to an uncomplicated site of power/resistance. In considering Little Manila less as a spectacle of modern life and more as a contested site of aesthetic/sensorial culture, I aim to provide a more complex account of its significance. In the second part, Central is portrayed as a landscape transformed through sensory experience each week. I take the example of Filipino food that is ceremonially eaten at Sunday gatherings, and how its taste, texture and aroma help embody these women as national subjects. I contrast the conviviality of eating Filipino fare with the cultural politics of food consumption in the city, elaborating how food is enmeshed with Chinese-Filipino corporeal and material relations. Finally, in the third part of the paper I bring these geographies of vision, sound, taste, texture and aroma together to consider how diasporic populations might be understood as producing different sensorial landscapes.

Although a methodology for researching sensory landscapes is far from apparent, and the practice and meaning of the several senses is difficult to capture in words, the importance of ethnographic research cannot be denied. I have therefore chosen a narrative strategy that begins with my own encounter with Little Manila, moves through domestic workers' experiences of Hong Kong domestic space, and then recounts the ritual phenomenon of gathering. I stress the importance of ethnographic fieldwork in perceiving these geographies, and suggest that insights about sensorial culture provide new maps of people and places in the city.

\section{Sensing the city}

During 1997/98 I completed a series of interviews with non-government organizations (NGOs) working on behalf of domestic workers in Hong Kong. These interviews explored extreme forms of domestic worker experience and the role activists play in mediating negative images of overseas Filipino women. My research had by and large focused on the imagery and political 
agendas of NGO members, and how their sophisticated theories of labour migration were selectively incorporating initiatives from a transnational arena. ${ }^{5}$ While there were domestic workers in these offices - particularly women seeking legal assistance concerning immigration requirements or court battles against employers - their embodied sense of the city was not derived from festive gatherings in Central, but from distressing circumstances in Hong Kong homes.

In NGO offices domestic work is a serious political issue. Individual cases of maltreatment and abuse are integrated into larger advocacy programmes addressing the politics of labour migration. Witness the entrance to one NGO office where an exhibit of newspaper articles reporting suspicious domestic worker deaths calls attention to discrimination against Filipinos in Hong Kong. Inside women are seeking paralegal assistance to fight cases against abusive employers or wrongful dismissal, in order to be permitted to seek further employment. These stories and cases paint a rather grim picture of life and work in the big city. At another NGO office several women are sleeping on the floor, having fled from employers in previous weeks. Three had not been paid in several months, two had never been granted a day off, one had been fed only leftovers and table scraps, and another had endured physical assaults from her employer. They were here to seek refuge and legal assistance, and in some cases help simply to return home.

In addition to offering crisis counselling and assistance with legal documents, NGOs ensure these cases are brought to the attention of the popular press, where they form part of a narrative of domestic work. Within this narrative, Filipino women are encoded as victims - as poor domestic workers enduring slave-like conditions. When supplemented by accounts of Hong Kong's history of bonded servants and the uneven nature of capitalist development, a naturalized representation of Hong Kong/Philippine social and economic geographies is transposed onto the social relations of domestic work (e.g. employer/employee, dominant/subordinate). The domestic sphere is thus a key site where such relations are seen to be playing out.

The maltreatment of domestic workers is an issue requiring urgent political attention. The cases described to me in NGO offices were viscerally shocking: one woman beaten with a broom for making a long-distance telephone call; another terminated under suspicion of theft and cast out on the doorstep at 2 a.m. The women I met complained of too little food to eat, of inadequate living quarters or having to sleep on the kitchen floor, and of language difficulties in communicating with employers. Although these cases represent a small number of extreme cases, they also indicate the power dynamics domestic workers navigate in the homes of foreign families. They may also represent the 'underlying cultural practices' of domestic work. ${ }^{6}$ NGOs play a strategic role in keeping these issues on the political table in Hong Kong and the Philippines, but the politics of this emphasis tends to highlight more extreme forms of bodily experience. While this is a necessary part of well-targeted advocacy work, these bruised, abandoned and malnourished bodies come to represent the experience of Filipinos in Hong Kong.

Some studies of domestic work have conceptualized Filipino women as corporeal subjects, often utilizing Foucauldian frameworks to discuss the 'disciplining' of these bodies through their employment and ethnic status. ${ }^{7}$ Constable focuses on domestic workers in Hong Kong and 
examines how Filipino women learn ways of disciplining themselves to avoid being recognized through negative ethnic stereotypes (for example as being lazy and/or sexually dangerous). Domestic workers wear simple clothing at work, cut their long hair short and, in an effort to come across as better servants, timetable their days into rigorous routines. Domestic workers thus become 'docile bodies', and unwittingly participate in their own oppression. Similarly, Pratt describes how government regulation and Canadian cultural sensibilities inscribe domestic work onto Filipino bodies in Vancouver, and how women mould their appearance and behaviour to avoid being seen through negative ethnic stereotypes. In exploring how women resist these images, Pratt argues that Filipino women are capable of resisting their highly circumscribed place within Canadian society. She also stresses how domestic workers use their own ethnic networks to find places in the city - including NGO offices - where they feel at home. Here, Pratt claims, they can 'refigure themselves as members of a group of exploited workers and citizens'. ${ }^{8}$

Foucauldian analyses that rely on the panoptic gaze have the tendency to coalesce and condense the gaze with hegemonic power. But this gaze has come under scrutiny by both feminist and postcolonial critics. ${ }^{9}$ Through these lenses domestic workers are recognized, at best, as resisting the power of ethnic stereotypes, rather than pursuing different ways to experience their social world. Although it is important to connect domestic work to the social and economic realities of labour migration and ethnic politics, and to interrogate the discrimination Filipino women experience overseas, these analyses imply that Filipino women have little room to negotiate their lives outside a domestic worker identity. Within this grid of identity and meaning, regrouping in NGO offices or congregating in Central merely become cathartic experiences and expressions of resistance where women identify themselves as exploited workers. In this way Little Manila is deprived of a broader political significance, and being Filipina is always about being a domestic worker. In Hong Kong, however, the majority of domestic workers do not tend to visit NGO offices unless they are in negative or abusive situations. Most women spend their week in a cramped apartment taking care of the needs of employers, and their time off in Little Manila. The six-day working week undoubtedly shapes women's lives on Sunday, but the relationship between these times and places escapes direct correspondence. Below I examine how women become embodied subjects that exceed - rather than merely resist - their denigrated role as 'maid'.

This is not to imply that Little Manila is somehow removed from power. It is the rather different assertion that Filipino women, like other diasporic communities, are weaving together aspects of culture and power that are difficult to unravel without new theoretical tools. In Little Manila domestic workers temporarily disrupt their position within a hierarchy of employer/employee social relations, and in the process define new networks and links across a range of spaces that redefine their Hong Kong identity. Put another way, Little Manila is a 'social space', ${ }^{10}$ a space saturated with Hong Kong/Philippines social and economic geographies that reflect the political economy of labour migration and domestic work. Filipino women - by virtue of their status as live-in domestic workers - have few places in their everyday lives to feel 'at home', and gathering in Central provides relief from working in a foreign culture. At the same time, the city itself is always active and fluid - filled with signs and meanings that connect different places, people and relationships at different junctures. Gathering in Central is certainly about a day away from a difficult working week, but it is also about the freedom of the streets where new 
vantage points on life and work abroad are possible. It is this transformation that disrupts binaries of employer/employee, as Filipino women connect the Philippines to Hong Kong in new ways, to different cultures and spaces, and their relationship to the city is transformed. I now turn to the visual space of Central to explore these ideas further.

\section{Hong Kong vistas}

The symbolic vista that has come to represent Hong Kong's urban culture helps to shape this visual sense of the city. Whether experienced through direct architectural encounters, photographs from the Star Ferry or through Jackie Chan action films, the visual experience of Hong Kong is bound up with issues of culture and cultural identity. Abbas has critically analysed this cultural space of (post)colonial Hong Kong, suggesting that it is architecture which upholds the colonial space of the metropolis. Architecture, he contends, 'has the dangerous potential of turning all of us, locals and visitors alike, into tourists gazing at a stable and monumental image'. 11 Film, on the other hand, through its moving images, enables a critical dismantling of this cultural space through its very problematization of the visual. Although the visual terrain of Little Manila is a valuable starting point for analysis, optical accounts (much like panoptic accounts) tend to drift into binary/hierarchical notions of power and resistance.

In visual terms, Little Manila could be understood as a part of Central's symbolic landscape: one that functions as both spectacle and subversion. If a spectacle is a social relationship mediated by images, ${ }^{12}$ then Sunday crowds expose the transformations occurring in the privacy of modern homes; that is, transforming employment opportunities for Chinese women. As Hong Kong joined the ranks of Asia's 'miracle' economies in the 1970s, the number of women prepared to work as domestics on a live-in basis dwindled. They were drawn to more autonomous and financially lucrative service and industry jobs, and a shortage of women willing to work as domestics become apparent. In 1975, 1,000 Filipino women arrived in Hong Kong on government-approved domestic worker contracts. By 1998 they numbered 140,500, and now form a vibrant foreign community. ${ }^{13}$ Little Manila brings these new social relations of households into public view, in a symbolic space that usually evokes economic prowess.

But Little Manila simultaneously critiques the disparities and dislocations of this global city. As poorer women migrate to wealthier countries to enhance their opportunities for social mobility, and as they congregate in central business districts to exchange news and hawk goods from home, confident narratives of economic progress are called into question. Filipino women gather by the hundreds in the open ground floor of the Hong Kong and Shanghai Bank, juxtaposing global capital with transnational labour migration. The inequalities of global capital, and the dislocation of Filipino women, are inscribed in a spatial relation. Much like Wilson's likening of the city to a 'palimpsest' or 'a writing block on which words are written, erased or partly erased

and written over, time and again', ${ }^{14}$ this assemblage re-inscribes the meaning of global capital at this site. On Sundays at least, Hong Kong's success as a 'miracle' economy is written over with migrant remittances and the petty trading of Pesos for Dollars, exposing the centrality of cheap migrant labour in building Asia’s ‘economic tigers'.

Few residents would be enthusiastic about incorporating Little Manila into Central's predominant meaning. In Hong Kong, as in Singapore, there are tensions between those who 
acknowledge the need for foreign women without a private residence to engage in leisure activities and those who would prefer domestic workers gather in less conspicuous places. ${ }^{15}$ Nevertheless, negative views of Sunday gathering have prompted the government and businesses to erect temporary barriers along cement ledges and in corners that might encourage sitting. Stringent regulations prohibiting hawking have also seen an increased police presence in the area. Witness, for example, Yang’s letter of 26 June 1998 to the South China Morning Post titled 'Congestion eyesore for tourists' (p. 20):

The heavy gatherings of Filipino domestic helpers in the streets (especially in Causeway Bay near Victoria Park) on Sundays has become a problem for pedestrians. As we all know, the streets are ... not designed for people to gather socially and eat together ... . They must also be an eyesore for tourists. Surely the Government could do something to ... prevent an important amenity in the city from being spoiled.

Or Chulani's letter of 8 July 1998, also in the South China Morning Post, 'Must clean up Central' (p.14):

I used to enjoy going for a stroll around Statue Square and the neighbouring Charter Garden on Sundays. Thanks to the Filipino maids who practically monopolise all the open areas and roads in Central, I now hate to come down to Central on Sundays . . . I would suggest that the Government immediately implement the following measures: prohibit squatting, hawking and eating in public areas; open normal traffic on all roads in Central so that the Filipino maids have no place to sit, squat and sleep . . . The Hong Kong and Shanghai Bank should erect barriers round its headquarters, to prevent crowds of Filipinos from gathering.

These letters are a regular feature in local newspapers and are reminiscent of the 1992 proposal to encourage Filipino women to congregate in underground car parks. ${ }^{16}$ They also suggest a preference for domestic workers to be 'out of sight'. Unlike their earlier Chinese counterparts, foreign domestic workers are a visible presence in public spaces. Although they are regularly seen during the working week - when they transport children to and from school, or shop for groceries in the markets - their presence in Little Manila is beyond such duties. Here they congregate collectively for pleasure and leisure rather than individual duty.

Each week a space that usually signifies a vibrant business culture turns into a festive Filipino gathering. From the early hours each Sunday, Central bustles with women attending church, remitting money home, sending packages through express parcel services, buying Filipino delicacies to share with friends and so on. But what does this disruption, or turning, mean? Consider Abbas' point of view:

Is Statue Square on Sundays an example then of the détournement or diversion of a space of power into a space of pleasure? This is unfortunately not entirely the case because the weekly congregations take place only by permission, and come Monday everything returns to 'normal'. No contestation has taken place. Perhaps 
the takeover of Central is more clearly an example of the fascination that the symbolic spaces of power exert on those excluded from them. The powerless are allowed to see Central - like looking at so many goods through a shop window but not to touch it. ${ }^{17}$

What this suggests is an aestheticization of space that relates more to images of postmodernity ${ }^{18}$ than debates about power, identity and struggles for equity or respect. Filipino women are left gazing at the monumental images of Hong Kong, merely embodying their (unfulfilled) desire. But the assumed depoliticizing force of aestheticization is a situated knowledge and is more relevant to phenomena such as shopping malls, theme parks and other spaces geared towards mass consumption. ${ }^{19}$ Central Hong Kong may typify postmodern visual consumption if viewed from the Star Ferry, one could argue, but Little Manila does not. To neglect the significance of this gathering as a negotiated space of ethnic and cultural identity, and as a place of 'the uncommodified activity of dreaming, ${ }^{20}$ is to deny Filipino women subjectivity. The aesthetics of Little Manila remain trapped within a binary view of power - of the powerful versus the powerless.

Let us detour, for a moment, to a different sense of the city - one saturated with aromas - to explore these issues of power further. After reading Yang's letter (quoted above) I felt impelled to revisit Victoria Park (the site of his complaint), since my own impression had not been the presence of 'heavy gatherings' of Filipino women in that part of the city. One Sunday I entered the park, and rather than being surrounded by great gatherings of Filipino women was overwhelmed by that marvellous aroma of Indonesian clove cigarettes. Wandering around Victoria Park, for me at least, confirmed statistics of the growing number of Indonesian domestic workers in Hong Kong. Although women from the Philippines have dominated this labour market since the 1970 s, there were 31,800 domestic workers from Indonesia in $1998 .^{21}$ In Victoria Park they too were enjoying their day off. The fact that the aroma of cloves and chatter in Indonesian dialects could elude Yang, or indeed that signs prohibiting hawing and littering had been posted in Tagalog and not Bahasa Indonesia, merely demonstrates the powerful associations between 'Filipino' and ‘domestic worker' in Hong Kong. ${ }^{22}$

More generally, different odours and aromas can create the effect of 'olfactory maps' of cities, which enable people to 'conceptualize their environment by way of smell' ${ }^{23}$ Olfactory geographies 'evoke place' as well as 'memories of place'. ${ }^{24}$ For some, cloves might create aromas with positive associations that signify inclusion, for others they can signify and distance cultural difference. Consider, for example, a letter to a Hong Kong newspaper which laments the 'filthy stench in the air late on Sunday evenings'. ${ }^{25}$ The use of 'filthy stench', with its implications of refuse and contamination, articulates with ongoing discussions about how to 'clean up' Central and indeed Hong Kong more generally. Why the city might need cleaning up is a matter of interpretation, and there looms a possibility that some residents desire the odourless experience of the city as it appears on film. ${ }^{26}$ 'Filth' and 'stench' are words usually associated with civic (un)cleanliness, but the perceived olfactory differences between social classes or ethnic communities produce, and are themselves produced by, classification systems which relate more to cultural ideologies than to odours or aromas themselves. ${ }^{27}$ Therefore, the 'filthy stench' of Central is not only disagreeable, it reaffirms unfavourable images of Filipino women as backward and unruly. Their apparent refusal to comply with modern sensibilities produces 
images of Filipino domestic workers as disorderly and undisciplined - in seeming contradiction to their employment as organizers of domestic space.

These contested sights and aromas suggest that aesthetics are not autonomous from their political, economic and social milieu. More importantly, they point to how differing aesthetic politics may be articulated through differing urban senses. The optical lens that situates Filipino women gazing at Hong Kong monuments almost colludes in excluding them from the dynamism of city life. The olfactory aesthetics and politics of Little Manila can, in contrast, be seen to disrupt the colonial space of Hong Kong architecture by dislocating its dominant visual meaning. On Sundays at least, Central's morphology and monuments are unable to construct Filipino women as colonial subjects, servants or voyeuristic consumers. Paying attention to the olfactory politics of Little Manila opens up the political possibilities of its aesthetics and recognizes how the senses help to create a place like 'home'. If we connect the senses to questions of power and the cultural economy of labour migration, then we may better understand the diverse ways migrants cope with living in global cities.

\section{Home cooking}

On Sunday, 31 August 1997, a date many will remember as the day of Princess Diana's car crash, I had been invited to a party for a domestic worker named Deenah who was fortunate to have her 30th birthday fall on her day off. ${ }^{28}$ Arlene, also a domestic worker and my part-time research assistant, arrived at 10.30 am to accompany me to the meeting place. Arlene is from Ifugao Province in the Philippines, but her friends are from various parts of Luzon (the Philippines' main northern island). There are some general rules of thumb for locating friends from different provinces in the Philippines: Cebuanos congregate around City Hall, Nueva Vizcayans in the northeastern part of Statue Square and Illocanos near the statue of Sir Thomas Jackson (popularly known as 'the black statue'). When Arlene became exhausted with conveying the details of Little Manila's regions she exclaimed: 'it's just like a map of the Philippines!' Regional networks are strong in Hong Kong, partly for reasons of language/dialect, but also because of networks of families and friends. New acquaintances are often introduced as sisters, cousins or aunts, or friends from high school, college or university.

We wandered around Statue Square and the congested streets leading up to World Wide Plaza, where we stopped to buy a cold drink. The crowds were unusually thick at this time of day, and it took a full 20 minutes to cross the mall and find a shop that sold Coke. Unable to find a seat amongst the hundreds of Filipino women, we went out to the streets and began looking for the party troupe. A few had congregated on a shop step near Giorgio Armani, and we sat to drink and wait. Arlene introduced me to Mary and Cha, who were comparing cosmetics they had purchased that morning. Cha decided to paint her fingernails for the party, lamenting that polish was 'too difficult' during the working week: 'My employer doesn't like it and anyway it just comes off when I wash the floor.' The step we sat on was watched over by a Chinese security guard employed to ensure no one crossed his plastic tape barrier, although everyone laughed as he scolded us for placing our shopping bags beyond the magic line. What he was guarding apart from a small horizontal piece of concrete - completely eluded me. Mary, who noticed my disdain, offered the explanation that he was 'just following orders'. 
When a critical mass had assembled we fought the crowds to the Hong Kong and Shanghai Bank, where we took a tram to the party site. From the tram stop we wandered to a small green square where the party was to be held, arriving just after midday. About 20 close friends had been invited, most of whom Deenah knew from the Philippines but including others she had met in Singapore. About one-third of those present had worked in Singapore or Saudi Arabia previously, but were happy to be in Hong Kong since it offered a minimum wage, regular days off and less government interference, and is only a short flight to the Philippines. Singapore is a cleaner and less densely populated city to live in, everyone agreed, but Hong Kong is exciting and lively and a good place to make money. More than half of the women were married, and had brought along letters - complete with photos of husbands and children - to read. As I glanced through snapshots and heard stories of children in school, and of new family homes and businesses financed by overseas work, Arlene commented: 'It's too sad that these families are not together.' She quickly flashed a mischievous grin, however, and claimed Mary's husband was so terribly ugly that she was desperate to work abroad. Everyone squealed with laughter. Mary retorted: 'I’m taking care of my family, experiencing life and seeing the world.'

We spent the next hour waiting for the last guests, who had to travel long distances from the New Territories. To pass the time we assembled into various poses for photos to be sent back to the Philippines. Some women read letters, Arlene switched on the portable CD player, and a few women sang along with the music. Deenah modelled a wig she had recently purchased while on holiday in Thailand, while others chatted about Giordano's latest bargains on tshirts. The festivities really began when Deenah opened several Tupperware dishes that contained food she had prepared for the party, and the air became filled with aromas of rice, ginger and vinegar. Deenah is permitted to cook Filipino food in her employers' home, and had prepared a series of Filipino delicacies including chicken adobo, pinakbet (vegetables) and bangus (fish). We were all provided with a paper plate and chopsticks and helped ourselves to the food. About half way into the meal, however, I noticed that chopsticks were quickly being replaced by thin plastic gloves that Deenah had also brought along. Deenah looked at me and queried: 'You like?' Asserting my own cultural capital, I abandoned my clumsy attempt at chopstick etiquette and opted for these more pliable eating utensils. Peals of laughter were soon replaced by endless conversations about what our favourite foods were, the availability of ingredients to make regional dishes and how much everyone missed eating rice with every meal. Filipinos often enjoy eating with their hands, but because there are few places in Hong Kong's parks and squares to wash up before or after eating, many women opt for disposable gloves. It was a moment of casting off Chinese customs to enjoy the taste, aroma and texture of home. 'We are', as Bell and Valentine have suggested, 'where we eat'. ${ }^{29}$

Birthday parties are a particularly good reason to celebrate, but they are not the only reason to enjoy the conviviality of Central. The simple pleasure of sharing a meal with family and friends is a welcome respite from the weekly routine of preparing meals for employers and eating alone in maids' quarters. Women can also relish an assortment of familiar tastes - some prepared personally for the day, others made by friends, hawkers or fast food outlets. 'We are where we eat' is more than an ironic aphorism, however, where food acquires its meaning through the place it is assembled and eaten. In Hong Kong it is the Philippines (home) that has to be prepared (cooked) for food to take on its homely significance. 
The Philippines is experienced each Sunday through a conscious invention of home - an imagining of place through food and other sensory practices that embody Filipino women as national subjects. 'Home cooking' thus becomes an active creation: a dislocation of place, a transformation of Central, a sense of home. In savouring Filipino food, for example, senses of taste, touch, vision and smell all become active. Eating thus becomes a productive and selfconscious pursuit, not merely an organic, innate or derivative activity. Putting aside chopsticks not only disrupts the routine of everyday eating, it is about enjoying eating with the hands. It is less about a refusal to use chopsticks than about enhancing flavour - a practice well known at home. The senses thus connect Hong Kong to the Philippines not through binary forms of power, but through alternative geographies of employment, work, travel and life experience.

There is a growing academic interest in food and 'foodways' (the routes through which food travels) that relate to two interrelated issues. On the one hand, there is growing recognition that the centralization of food production and consumption policies tends to eliminate regional varieties of food products in local, regional and global markets. ${ }^{30}$ On the other hand, an emphasis on the importance of material culture to contemporary cosmopolitan experience has increased awareness that food might be a pertinent example of an 'entangled' object. ${ }^{31}$ Bringing these perspectives together to consider the meaning of food in Hong Kong provides insights about the importance of 'home cooking' to migrant populations around the world. ${ }^{32}$ For it is the entangling of foodways in webs of culture, economics and politics which enable the presence of some foods and not others in shops, restaurants or households. The absence of familiar material culture, and its subtle evocations of home, is surely one of the most profound dislocations of transnational migration.

It is common knowledge that the preparation and consumption of food in Hong Kong is important in defining its vibrant culinary culture, but it is less well known that these practices also help define the awkward relationships that arise when a foreign worker enters the space of the family. Deenah, for example, is not representative of the domestic worker population in that many women claim they are either not permitted to cook or simply do not feel comfortable preparing Filipino foods in Chinese homes. I gleaned this knowledge from a number of women who were eating snacks in the Filipino dry goods shops that are common in Central, and have more recently opened doors in neighbourhoods such as Mei Foo, Sai Kung and Tuen Mun. Indeed, food consumption practices in Chinese homes - as everywhere - are 'crossed by complex webs of power relations between household members' ${ }^{33}$

Filipino women are employed to organise domestic spaces, but this may or may not include the kitchen, depending on the disposition of the employer. In some instances Filipino women are perceived as inept in operating household appliances - a stereotype generated in the 1970s, when domestic workers were recruited from rural Philippines. In other households women claim their employers deem Filipino food to have a 'bad smell', and prefer to eat these foods outside the workplace. Equally important might be a desire for employers to maintain control over the visceral substances that influence Cantonese health, vitality and longevity. It would be a great responsibility for foreign women to purchase and prepare the hundreds of herbs and tonics used in everyday cooking. These power relations of food preparation are constituted at least partly through Chinese vulnerabilities, notions of 'cultural pollution ${ }^{34}$ and stereotypes of Filipino women as poor and uneducated. 
A growing number of Filipino dry goods shops and fast food outlets cater to weekday shoppers and Sunday picnics. This food is clearly packaged for migrant workers, however, rather than constituting part of a cosmopolitan food culture in the city. In the two outlets of Jollibee (the Philippines' equivalent of McDonalds), for example, the clientele is almost exclusively Filipino. This contrasts starkly with the dozens of franchises of McDonalds dominated by Chinese patrons. Jollibee serves classic Filipino snack foods such as fried chicken with rice and uniquely seasoned hamburgers - foods that do not seem to appeal to the Chinese palate. Furthermore, there are simply too few places for more than 100,000 women to buy Filipino fare, helping to galvanize a vibrant food-hawking culture in Statue Square. Entrepreneurial domestic workers with sympathetic employers earn extra money through this 'side business' each week and, if they evade temporary raids by the police, fill the gap in certified eating establishments. Filipino food, in Cantonese homes or in its 'fast' forms, does not appear to represent the processes of 'acculturation and hybridization' that have come to characterize popular ethnic cuisine in Hong Kong (Indian, Japanese, Thai, Western) or in the West. ${ }^{35}$ Although this disconnection between food cultures might suggest that Filipino cuisine lacks exotic appeal for the discriminating Chinese palate, it also signifies the social and cultural distance between employers and domestic workers. It is through the process of ingesting Filipino food, however, that domestic workers create new associations between Hong Kong and the Philippines. Ethnic cuisine 'only becomes a self-conscious, subjective reality when ethnic boundaries are crossed' ${ }^{36}$ Whether at a birthday party on the street or in a fast food outlet in Central, eating chicken adobo becomes a way in which nation and ethnicity are resignified. These foods become national dishes through their appearance in Hong Kong, and their consumption is suffused with cultural politics.

In summary, Filipino food is entangled with three aspects of Chinese-Filipino material and corporeal relations. First, food becomes contested matter in Hong Kong homes. Claims about food odours are impossible to disentangle from ethnic stereotypes, and whether or not domestic workers are allowed to cook Filipino food is an issue of power within households. Second, and partly as a result, Filipino food undergoes a process of revision when it crosses ethnic boundaries. It articulates national identity in a way it could not in the Philippines, and on Sundays becomes a positive signification of cultural difference. Finally, Filipino food evokes familiar senses of taste-texture-aroma and, particularly when consumed in Central, evokes a sense of home: Little Manila. This latter process incorporates elements of history and memory, of past and present times and spaces, helping to create a familiar place where memories of life in the Philippines and migration to Hong Kong might be explored from another perspective.

\section{Producing sensory landscapes}

Sensory landscapes of cities suggest less conventional forms of ethnic politics, and reveal how diasporic populations find original ways of engaging with urban life. Little Manila is a hybrid site - one that creates new connections between Hong Kong and the Philippines and between being a domestic worker and a Filipina. Much like Appadurai's 'ethnoscapes', this reproduction of culture and identity fails to be recuperated through notions of essential national identities or marginal ethnic groups. ${ }^{37}$ As Appadurai argues: 
As groups migrate, regroup in new locations, reconstruct their histories, and reconfigure their ethnic projects, the ethno in ethnography takes on a slippery, nonlocalized quality, to which the descriptive practices of anthropology will have to respond. The landscapes of group identity - the ethnoscapes - around the world are no longer familiar anthropological objects, insofar as groups are no longer tightly territorialized, spatially bounded, historically unselfconscious, or culturally homogeneous. $^{38}$

Little Manila is such an ethnoscape, a frame of reference for life and work abroad. I now turn to the dynamic interactions between material culture, memory and the senses that help give Little Manila these original and hybrid meanings.

Perception and memory connect the body with material culture. As women sit on straw mats to eat pinakbet or adobo, or stand in enormous queues to buy familiar goods from the Philippine Products Store, there is constant chatter about home: 'How is your daughter's schooling?' 'Do you have photos of Alma's wedding?' 'Did you hear that Fe's husband is unfaithful?' But these conversations are also punctuated with ones about daily life in Hong Kong: 'When are you finish-contract?' 'How is your employer treating you?' 'Can you speak Cantonese yet?' Little Manila is not an 'authentic' but a simulated home. ${ }^{39}$ It is produced through a complex articulation of nostalgia and desire within a different and contemporary context. Central Hong Kong is, after all, not Manila.

In relation to current debates about the aesthetics of cities, nostalgia is usually understood as the inauthentic or depthless consumption of history. History is presented as decoration, and is intended for visual consumption. But the role of nostalgia in transforming Central into Little Manila does require a depth of emotion, and is rather like Seremetakis' sense of the word in that it evokes the desire or longing to journey in time and space. ${ }^{40}$ This journey is embarked on from and in Little Manila, a place which captures everyday experience from another 'oblique angle' and 'gives rise to a new or alternative perceptual landscape'. ${ }^{41}$ In other words, the Sunday journey from Hong Kong to the Philippines constitutes, and is itself constituted through, a landscape that simulates home while enabling new perspectives on the past and the present.

Material cultures, and the senses they evoke, are integral to this journey. As discussed above, the touch and taste of food are important in embodying Filipino women as national subjects. But sensory landscapes are about the whole body - including sight/vision. Let me consider this point by drawing on the peculiar effect of photographs of distant loved ones placed on the walls of Philippine homes. ${ }^{42}$ While in some cultures photographs of overseas family members signify absence, in the Philippines these photos enhance presence in that they recreate moments of togetherness which have been shared between family and friends. Photographs from overseas may transform domestic spaces in the Philippines, but in Little Manila this process works in the other direction. Snapshots of loved ones viewed in Central remind women why they are in Hong Kong - to meet family responsibilities - and have the effect of bringing the Philippines into the foreground. On the other hand, snapshots taken in Central rarely include monumental architecture, and are more likely to include friends, Sunday picnics or photos that impart Hong Kong's wealth (e.g. poses in front of a Mercedes). Viewing photos of loved ones at Deenah's party inspired nostalgia, reflection and very Filipino jokes. Photos also serve to introduce lives at 
home to new friends met while overseas, and evoke a sense of family. Photographs reinforce these social relations and generate a transnational sense of communal life.

Other objects of material culture facilitate this journey. A similar case could be made for the letters that are read or written in Little Manila as they embellish photographic images with narratives. The letters of overseas Filipino women represent tremendous subjective power, and Tadiar has argued that letters represent 'doses of human time, time with subjective value'. ${ }^{43}$ As with photos, letters play a role in constituting Little Manila's perceptual landscape, for not only do letters create human time, they create a place of contemplation and subjective meaning where Hong Kong is experienced from another perspective. Life and work is described/written not merely from the stable identity of domestic worker but from the alternative perspectives of sisters, daughters, wives, cousins and friends. Moreover, these letters rewrite women's marginal economic status in Hong Kong with economic success stories of new homes and businesses in the Philippines. Like photographs, letters travel in both directions, and form a part of a selfreflexive experience of life abroad.

This dynamic interaction between food, photos, letters and other artifacts enables the production of an alternative sensorium called Little Manila. If sensory landscapes are constituted by emotional and historical layerings that evoke gestures and discourses that open up their stratigraphy, ${ }^{44}$ then Little Manila can be understood through the multiple meanings of food, through the photographs and letters that enhance the presence of family and friends and through the melodic songs of street vendors. All of these are suffused with echoes of 'home'.

\section{Conclusion}

The aesthetic awareness of the senses ... plays a foundational role in experience, which, in turn, is the heart of ethnographic fieldwork. ${ }^{45}$

The consumption of Filipino food in Hong Kong is a salient example of how everyday experience can become a performative politics of ethnic identity. Much like the global commodity which reshapes global cultural landscapes, Filipino food articulates both 'place and movement - and, through those, identity and identification' ${ }^{46}$ Along with music, letters and photographs, food helps to transform Central into Little Manila each week, and allow women to disrupt the social and economic geographies that attribute them with a stable (and marginal) domestic worker identity. The sounds, sights and aromas of Little Manila dislocate the authoritative visual space of Hong Kong culture, and create a place where Filipino women feel at home. In so doing, women find new ways of engaging with city life, and their relation to the city is transformed. These are the geographies of Hong Kong-based Filipino identities - ones that allow domestic workers to be involved in the production of cosmopolitan culture abroad.

The stories told here show how domestic workers are able to negotiate relations which are about more than globalization, gendered labour migration or ethnic discrimination. But these are still relations of power. Geographies of the senses articulate the cultural politics of difference and inequality, making new spatial connections between home/away and between dominant/subordinate and power/resistance. While Little Manila is always about the politics of labour migration and domestic work, it is also inhabited by unique signs and symbols that allow 
Filipino women to define their own social worlds and their own, situated resistances. In so doing, they transgress their circumscribed role as 'maid'. Geographies of these senses tell us something different about urban culture and diasporic experience, providing fresh insights to corporeal relations. Conceiving them as an embodied practice enables new maps of the city - maps integral to embodied cultural geographies.

\section{Notes}

1 A. Abbas, Hong Kong: culture and the politics of disappearance (Hong Kong, Hong Kong University Press, 1997), p. 4.

2 C. N. Seremetakis, ed., The senses still: perception and memory as material culture in modernity (Chicago, University of Chicago Press, 1994).

${ }^{3}$ P. Rodaway, Sensuous geographies: body, sense and place (London, Routledge, 1994).

${ }^{4}$ Seremetakis, The senses still; see also C. Classen, D. Howes and A. Synott, Aroma:

The cultural history of smell (London, Routledge, 1994); P. Stoller, The taste of ethnographic things: the senses in anthropology (Philadelphia, University of Pennsylvania Press,1989).

${ }^{5}$ See L. Law, 'Sites of transnational activism: Filipino NGOs in Hong Kong', in B. Yeoh, P. Teo and S. Huang, eds, Gender politics in the Asia Pacific region (London, Routledge, 2002), pp.205-222.

${ }^{6}$ N. Constable, Maid to order in Hong Kong: stories of Filipina workers (Ithaca, NY, Cornell University Press, 1997), p. xiv.

${ }^{7}$ See ibid.; G. Pratt, 'Inscribing domestic work on Filipina bodies', in H. Nast and S.

Pile, eds, Places through the body (London, Routledge, 1998), pp. 283-304.

${ }^{8}$ Ibid., p. 297.

${ }^{9}$ For a feminist critique of Foucault see N. Hartsock, 'Foucault on power: a theory for women?', in L. J. Nicholson, ed., Feminism/postmodernism (New York, Routledge, 1990), pp. 157-75. For a postcolonial critique of the gaze, see H. Bhabha, The location of culture (New York, Routledge, 1994).

${ }^{10}$ H. Lefebvre, The production of space, trans. D. Nicolson-Smith (Oxford, Blackwell, 1991).

${ }^{11}$ Abbas, Hong Kong, p. 65.

${ }^{12}$ G. Debord, Society of the spectacle (Detroit, Black \& Red, 1977), p. 4. I thank one of my referees for directing me to this work and for suggesting I clarify my point.

${ }^{13}$ AMC (Asian Migrant Centre), Asian migrant yearbook (Hong Kong, AMC, 1999).

${ }^{14}$ E. Wilson, 'Looking backward: nostalgia and the city', in S. Westwood and J. Williams, eds, Imagining cities: scripts, signs, memory (London, Routledge, 1997), p. 129.

${ }^{15}$ Cf. B. Yeoh and S. Huang, 'Negotiating public space: strategies and styles of migrant female domestic workers in Singapore’, Urban studies 35 (1998), pp. 583-602; B. Yeoh, and S. Huang, 'Spaces at the margins: migrant domestic workers and the development of civil society', Environment and planning A 31(1999), pp. 1149-67.

${ }^{16}$ C. Lowe, 'The outsiders voice: discourse and identity among the Filipino domestic workers in Hong Kong', paper presented at the International Conference on Gender and Development in Asia, 27-9 Nov. 1997, Chinese University of Hong Kong, Hong Kong, SAR, China; Constable, Maid to order in Hong Kong.

17 Abbas, Hong Kong, p. 87.

18 Cf. D. Harvey, The condition of postmodernity (Oxford, Blackwell, 1989); F. Jameson, 'Postmodernism or the cultural logic of late capitalism', New left review 146 (1984), pp. 53-92. 
19 J. M. Jacobs, 'Staging difference: aestheticization and the politics of difference in contemporary cities', in R. Fincher and J. M. Jacobs, eds, Cities of difference (New York, Guilford Press, 1998), p. 252-78.

${ }^{20}$ N. Tadiar, 'Domestic bodies of the Philippines', Sojourn: journal of social issues in Southeast Asia 12 (1997), p. 181.

${ }^{21}$ AMC, Asian migrant yearbook.

${ }^{22}$ In Hong Kong a popular term to describe or address a domestic worker is banmui. Ban is the last syllable in the Cantonese word for the Philippines, and mui suggests a young girl (as in muijai for young maidservant). The identity of domestic worker is therefore thoroughly associated with being Filipino. Constable argues that this form of address 'carries the same connotations as "girl”: perpetual immaturity, inferiority, and submission' (Maid to order in Hong Kong, p. 77).

${ }^{23}$ Classen et al., Aroma, p. 18.

${ }^{24}$ Rodaway, Sensuous geographies, p. 68.

${ }^{25}$ Cited in Constable, Maid to order in Hong Kong, p. 36.

26 Strate, for example, discusses how the media create deodorized representations for their audiences. This might also be the case for cities such as Hong Kong, where visual culture dominates the senses. See L. Strate, 'Media and the sense of smell', in G. Grumpet and R. Cathcart, eds, Inter-media (Oxford, Oxford University Press, 1986). See also Classen et al., Aroma, p. 175.

27 Ibid.

${ }^{28}$ I mention Diana's death here partly because of its situated representation in the Hong Kong press. Few countries, I expect, would have noted that Diana had a Filipino domestic worker.

${ }^{29}$ D. Bell and G. Valentine, Consuming geographies: we are where we eat (London, Routledge, 1997).

${ }^{30}$ Seremetakis, The senses still.

${ }^{31}$ P. Crang, 'Displacement, consumption, and identity', Environment and planning A 28 (1996), pp. 47-67; cf. N. Thomas, Entangled objects: exchange, material culture and capitalism in the Pacific (Cambridge, MA, Harvard University Press, 1991).

${ }^{32}$ See also Seremetakis, The senses still for how these issues/themes can be brought together.

${ }^{33}$ Bell and Valentine, Consuming geographies, p. 59. See also Pratt, 'Inscribing domestic work on Filipina bodies', on Philippine food in Vancouver.

${ }^{34}$ M. Douglas, Purity and danger: an analysis of the concepts of pollution and taboo (London, Routledge, 1966).

${ }^{35}$ Bell and Valentine, Consuming geographies, p. 16.

${ }^{36}$ Cited in ibid., p. 114.

37 A. Appadurai, Modernity at large: cultural dimensions of globalisation (Minneapolis, University of Minnesota Press, 1996).

${ }^{38}$ Ibid., p. 48.

39 J. Baudrillard, Simulacra and simulation, trans. S. F. Glaser (Ann Arbor, University of Michigan Press, 1995).

${ }^{40}$ Seremetakis, The senses still, p. 4.

${ }^{41}$ Ibid., p. 14.

${ }^{42}$ For a discussion of photos in Filipino homes, see F. Cannell, Power and intimacy in the Christian Philippines (Cambridge, Cambridge University Press, 1999); F. Cannell, 'Filipino kinship, phantom houses and fantasies of the feminine', paper presented at the Globalization and 
Ethnicity Conference, Faculty of Social Sciences, Research Centre Religion and Society, Amsterdam, Dec. 1997.

${ }^{43}$ Tadiar, 'Domestic bodies in the Philippines', p. 178.

${ }^{44}$ Seremetakis, The senses still, p. 7.

${ }^{45}$ Stoller, The taste of ethnographic things, p. 152.

${ }^{46}$ Bell and Valentine, Consuming geographies, p. 191. 